\title{
Purification and Characterization of Antifungal Substance Ac-1 Produced by a Streptomyces sp. AB-88M
}

\author{
Nobuaki MATSUYAMA*
}

Key words: Streptomyces sp., antifungal antibiotic, Ac-1.

A microorganism which is antagonistic to various phytopathogenic fungi was isolated from the surface of a pear leaf in 1988 and designated as an isolate $A B-88 M^{4}$. The morphological characteristics of this organism were the formation of spiral spore chains and sporangium-like bodies. The spiral spore chains and aerial mycelia intertwined and turned into a spherical sporangium-like body $(3-10 \mu \mathrm{m})$. By the scanning electron microscope (SEM) observation, the absence of the sporangial-wall was certified and so, this structure was decided as a pseudosporangium. These pseudosporangia fused each other forming a larger and irregular structure ${ }^{4)}$. This pseudosporangium released abundant spores at immersion in water. The spore was oval to spherical $(0.6 \times 0.7 \mu \mathrm{m})$ and immobile with smooth surface. The analytical data of peptidoglycan layer ${ }^{8)}$ showed that the cell-wall type of this antagonistic microorganism is Type I (Streptomyces type). From whole morphological, biological and biochemical data ${ }^{4,5)}$, this organism was identified as Streptomyces sp. Before 1986 this type of actinomycete had been grouped as Actinosporangium and this genus was recently transferred to the genus Streptomyces ${ }^{2,3}$. In this experiment the isolation of the antibiotic produced by this actinomycete was conducted. The abstract has been reported elsewhere ${ }^{5}$ and the details will be contributed in this report.

The producer Streptomyces sp. AB- $88 \mathrm{M}$ was inoculated on the PSA medium $[1,000 \mathrm{ml}$ of potato (200 g) decoction, $20 \mathrm{~g}$ sucrose, $18 \mathrm{~g}$ agar, $\mathrm{pH}$ 7.3] and the modified Bennett's medium [1 g yeast extract (Wako Co.), $1 \mathrm{~g}$ beef extract (Kyokuto Co.), $2 \mathrm{~g}$ casein hydrolysate (Sigma Co.), $10 \mathrm{~g}$ maltose, $1,000 \mathrm{ml}$ dist. water, $18 \mathrm{~g}$ agar, $\mathrm{pH} \mathrm{7.3]} \mathrm{in} \mathrm{petri} \mathrm{dishes} \mathrm{and} \mathrm{incubated} \mathrm{at} 28^{\circ} \mathrm{C}$ for 2 days. The mycelial disk ( $5 \mathrm{~mm}$ in diameter) of the indicator fungus was confronted keeping distance $2 \mathrm{~cm}$ from the colony of the producer. Then, each petri dish was incubated at $28^{\circ} \mathrm{C}\left(20^{\circ} \mathrm{C}\right.$ in the case of Botrytis cinerea) for 7 days and the antagonistic activity was estimated. The indicator fungi tested were as follows: Pyricularia oryzae Cavara (Naga 69-150), Pyricularia sp. (MZSV-1-1), Botrytis cinerea Persoon (85202R, 85299S), Pestalotia funerea Desmazieres (Ka-5), Helminthosporium maydis Nisikado et Miyake (NIAS-HM), Helminthosporium oryzae Miyabe et Hori (Kyu No. 10), Rhizoctonia solani Kühn (R57), Alternaria kikuchiana Tanaka (A4-5-2), Fusarium roseum f. sp. cerealis Snyder et Hansen (Kyu 78-13), Fusarium solani f. sp. phaseoli Snyder et Hansen (SUF386), Fusarium oxysporum f. sp. melonis Snyder et Hansen (KF320), Sclerotium rolfsii Saccardo (S2-1-2). The antagonistic activity was graded as : - not inhibited, + slightly inhibited, ++ inhibited, +++ strongly inhibited the mycelial growth of the indicator fungi.

Isolate AB-88M was shake-cultured with the modified Bennett's medium in Sakaguchi flasks at $30^{\circ} \mathrm{C}$ for 10 days. The culture fluid was centrifuged at $4,000 \times g$ for $20 \mathrm{~min}$. The supernatant obtained was shaked with equal volume of ethylacetate or chloroform in a separation funnel. The extract was concentrated in vacuo by a rotary evaporator at less than $40^{\circ} \mathrm{C}$. After drying with $\mathrm{N}_{2}$ gas blowing, the residue was dissolved in $90 \%$ aqueous methanol and subjected to the reverse phase Lobar RP-18 (Merck Co.) column and eluted with $90 \%$ aqueous methanol monitoring at $254 \mathrm{~nm}$. The active fraction was diluted with twice volume of distilled water

\footnotetext{
* Faculty of Agriculture, Kyushu University, Fukuoka 812, Japan 九州大学農学部
} 
and shaked with a small volume of chloroform. The active substance was easily transferred to the chloroform and this fraction was subjected to silica gel thin layer chromatography (TLC) with two kinds of developing solvent such as chloroform-methanol $(9: 1 \mathrm{v} / \mathrm{v}, R f 0.66)$ and benzene-acetone-methanol $(28: 7: 4 \mathrm{v} / \mathrm{v}, \operatorname{Rf} 0.45)$.

The reddish band on the plate was scraped and eluted with chloroform-methanol $(2: 1 \mathrm{v} / \mathrm{v})$. The eluate was dried with $\mathrm{N}_{2}$ gas blowing and dissolved in $80 \%$ aqueous methanol. Then, it was subjected to the reverse phase preparative high performance liquid chromatography (HPLC, Gilson Model 303) with C-18 M\&S column $(20 \times 250 \mathrm{~mm})$ and eluted with $80 \%$ aqueous methanol at flow rate $5 \mathrm{ml} / \mathrm{min}$ (Rt $23.5 \mathrm{~min}$ ) monitoring at $313 \mathrm{~nm}$. The active substance was transferred to a small volume of chloroform as stated before and recrystallized by the addition of $n$-hexane. Ultraviolet-visible light (UV/VIS) spectrum was obtained by the UV spectrophotometer (Hitachi Model 100-60) subjecting the methanol solution. Infra-red (IR) spectrum was obtained by using IR spectrophotometer (Jasco Model A-100) equipped with the beam condenser BC-2. To avoid a loss of the sample, $\mathrm{KBr}$ micro-disk method was used in the analysis. For the decision of molecular weight of this substance, the fast atom bombardment mass-spectrometry (FAB-MS(+), JEOL JMS-DX300) and the low resolution electron impact ionization mass-spectrometry (LR-EIMS, JEOLJMS-300) were conducted. In the case of FAB-MS, chloroform- $n$-nitrobenzylalcohol was used as a solvent for analysis. The molecular formula was decided by the high resolution electron impact ionization mass-spectrometry (HR-EIMS, JEOL JMS-DX300) analysis.

The isolate $\mathrm{AB}-88 \mathrm{M}$ is antagonistic to various phytopathogenic fungi. As can be seen in Table 1, this organism inhibited the growth of most fungi tested. Especially, the inhibition was distinct against Pyricularia, Botrytis, Pestalotia and Helminthosporium spp. The antagonistic activity to Fusarium roseum f. sp. cerealis was also obvious, but not so severe against other Fusarium spp. Of the interest, this actinomycete was highly antagonistic to the causal agents of the air borne diseases and not so antagonistic against those of the soil borne diseases.

An antifungal antibiotic was extracted from culture filtrate easily by chloroform or ethylacetate and purified by TLCs, reverse phase LC \& HPLC and recrystallization. This substance was dark-red amorphous substance and designated as Ac-1. The reddish color turned into bluish-purple by the spraying of $1 \mathrm{~N} \mathrm{NaOH}$ solution or $0.25 \%$ methanol solution of magnesium acetate on the TLC plate. It has been well-documented that some Streptomyces spp. especially

Table 1. Antifung $\cdot$ activity of Streptomyces sp. AB-88M against various phytopathogenic fungi

\begin{tabular}{lcc}
\hline \multicolumn{1}{c}{ Indicator fungi } & PSA medium & Bennett's medium \\
\hline Pyricularia oryzae & +++ & +++ \\
Pyricularia sp. & +++ & +++ \\
Botrytis cinerea $(\mathbf{R})$ & +++ & +++ \\
(S) & +++ & +++ \\
Pestalotia funerea & +++ & +++ \\
Helminthosporium maydis & +++ & +++ \\
Helminthosporium oryzae & +++ & +++ \\
Fusarium roseum f. sp. cerealis & +++ & +++ \\
Rhizoctonia solani & ++ & ++ \\
Alternaria kikuchiana & ++ & ++ \\
Fusarium solani f. sp. phaseoli & + & + \\
Fusarium oxysporum f. sp. melonis & + & + \\
Sclerotium rolfsii & + & + \\
\hline
\end{tabular}

The producer Streptomyces sp. AB-88M was confronted against various indicator fungi on the PSA and Bennett's media.

(R): Resistant strain against thiophanate-methyl and benomyl.

(S) : Susceptible strain against the chemicals stated above. 


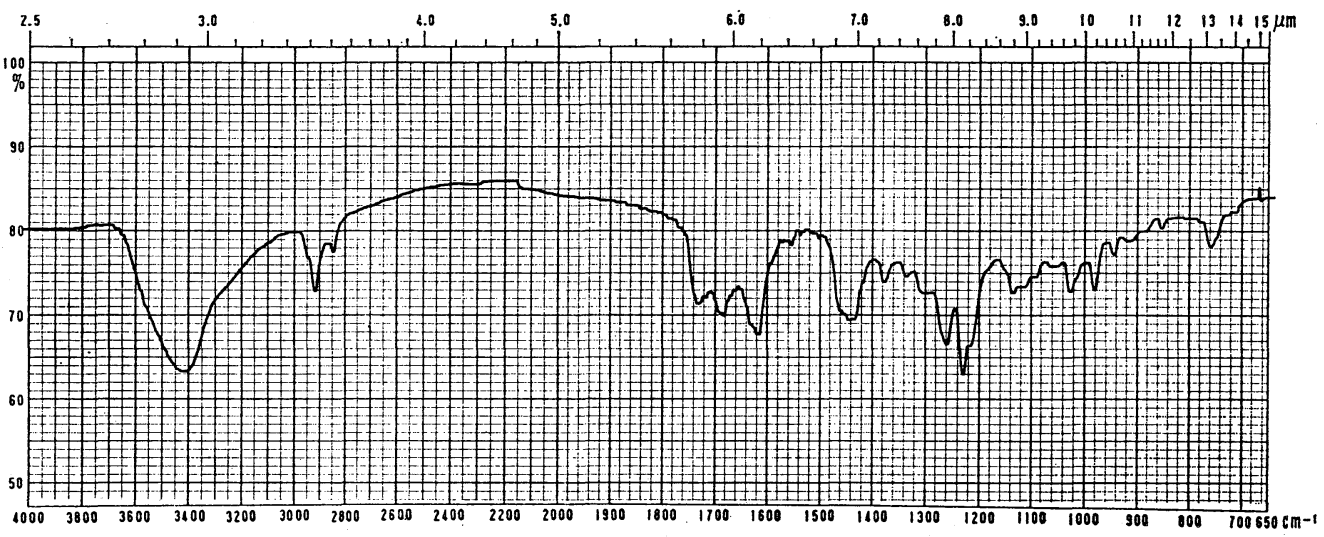

Fig. 1. Infra-red spectrum of antifungal substance Ac-1. $\mathrm{KBr}$ micro-disk was used.

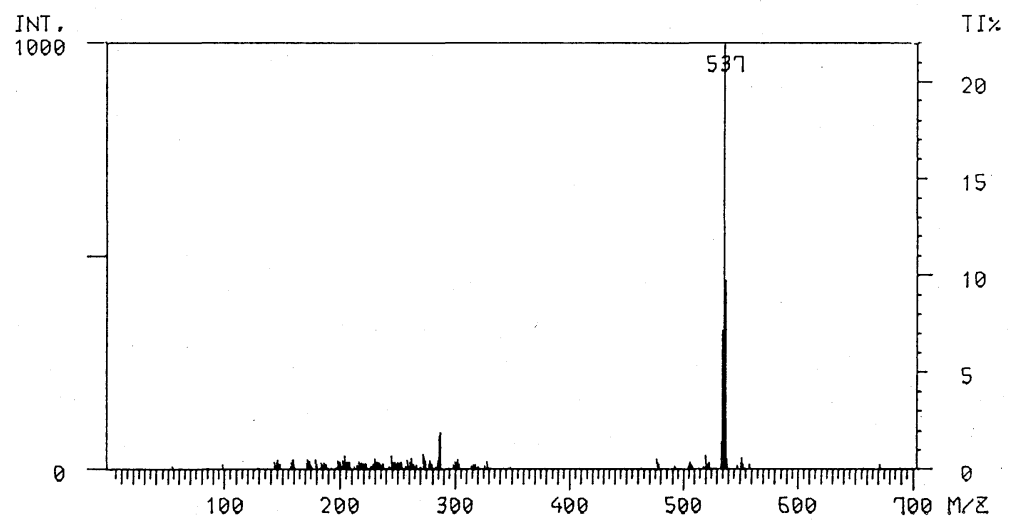

Fig. 2. The positive ion FAB mass spectrometry of the antifungal substance Ac-1. Number 537 shows the value of $(\mathrm{M}+\mathrm{H})^{+}$and indicates the molecular weight of Ac-1 is 536 . This value was certified by the results of LR, HR-EIMS. Ion source accel V: $2 \mathrm{kV}, \mathrm{X}_{\theta}{ }^{0}$ accel V: $5 \mathrm{keV}$. Solvent: $\mathrm{CHCl}_{\mathbf{3}}+n$-nitrobenzylalcohol.

the isolates which were formerly classified as Actinosporangium spp. produced various anthracycline antibiotics ${ }^{1,6,7)}$. UV/VIS spectrum of Ac-1 showed absorption peak at 210, 237, 313 and $509 \mathrm{~nm}$ and partly resembled with that of an anthracycline antibiotic produced by Actinosporangium bohemicum ${ }^{6}$. Such resemblance was also observed in the IR spectrum shown in Fig. 1. The molecular weight of Ac-1 was decided as MW 536 by the results of FAB-MS(+) and LR-EIMS (Fig. 2). Molecular formula was decided as $\mathrm{C}_{34} \mathrm{H}_{16} \mathrm{O}_{7}$ by HR-EIMS analysis.

The species name of this Streptomyces and the chemical structure of this antibiotic Ac-1 will be decided in future study.

The author is grateful to Prof. Dr. E. Taniguchi, Faculty of Agriculture in Kyushu University and to Dr. A. Seino of BANYU-SEIYAKU Co. for their useful advices. The author is indebted to the Dr. R. Isobe of Faculty of Pharmaceutical Science in Kyushu University for taking mass spectra and to Dr. K. Tsuno of author's laboratory for taking SEM photographs.

\section{Literature cited}

1. Bush, J.A. and Bradner, W.T. (1982). Production and biological activity of marcellomycin, an antitumor anthracycline antibiotic, and taxonomy of the producing organism. J. Antibiotics 35: 11741183. 
2. Goodfellow, M., Williams, S.T. and Alderson, G. (1986). Transfer of Actinosporangium violaceum Krasil'nikov and Yuan, Actinosporangium vitaminophilum Shomura et al. and Actinopycnidium caeruleum Krasil'nikov to genus Streptomyces, with amended descriptions of the species. Syst. Appl. Microbiol. 8: 61-64.

3. Kudo, T. and Seino, A. (1987). Transfer of Streptosporangium indiaense Gupta 1965 to the genus Streptomyces as Streptomyces indiaensis (Gupta 1965) comb. nov. Int. J. Syst. Bacteriol. 37: 241244.

4. Matsuyama, N. (1989). On an antibiotic producing microorganism AB-88M I. The characteristics of the producer. Ann. Phytopath. Soc. Japan 56: 106 (Abstr.).

5. Matsuyama, N. (1990). On an antibiotic producing microorganism AB-88M II. Purification of the antibiotic. Ann. Phytopath. Soc. Japan 56: 372 (Abstr.).

6. Nettleton, D.E., Jr., Bradner, W.T., Bush, J.A., Coon, A.B., Moseley, J.E., Myllymaki, R.W., O’Herron, F.A., Schreiber, R.H. and Vulcano, A.L. (1977). New antitumor antibiotics: Musettamycin and Marcellomycin from bohemic acid complex. J. Antibiotics 30: 525-529.

7. Oki, T., Shibamoto, N., Matsuzawa, Y., Ogasawara, T., Yoshimoto, A., Kitamura, I., Inui, T., Nagasawa, H., Takeuchi, T. and Umezawa, H. (1977). Production of nineteen anthracyclic compounds by Streptomyces galilaeus MA 144-M1. J. Antibiotics 30: 683-687.

8. Suzuki, K. (1987). In Bacterial Identification in Accordance with Recent Taxonomy (Education Committee of Japan Bact. Soc. eds.). Saikon-shuppan, Tokyo. pp. 74-79.

\section{和 文 摘 要}

\section{松山宣明 : Streptomyces 属菌 AB-88M 株が産生する抗糸状菌物質 Ac-1 の精製とその諸性質}

ナシ葉葉上から分離された抗系状菌物質産生性微生物 AB-88M 株は Streptomyces 属菌と同定された。本 菌は Pyricularia oryzae, Pyricularia sp., Botrytis cinerea, Pestalotia funerea, Helminthosporium maydis, Helminthosporium oryzae, Fusarium roseum $\mathrm{f}$. sp. cerealis に特に強い抗菌活性を示したが Fusarium solani $\mathrm{f}$. sp. phaseoli, Fusarium oxysporum f. sp. melonis, Sclerotium rolfsii にはほとんど活性を示さなかった。本放 線菌をべネット液体培地で $30^{\circ} \mathrm{C}, 10$ 日間振とう培養後, 遠沈上清から活性物質を等量のクロロフォルムま たは酢酸エチルにより振出した。さらに 2 種の展開溶媒 (chloroform-methanol 9:1, benzene-acetonemethanol 28:7:4 v/v) によるシリカゲル薄層クロマトグラフィー, 逆相系液体クロマトグラフィー (RP-18, $90 \%$ methanol), 分取型逆相系高速液体クロマトグラフィー (C-18, 80\% methanol) および $n$-hexane による 再結晶により精製し得られた暗赤色不定形結晶を Ac-1 と呼称した。各種質量分析の結果から，Ac-1 の分

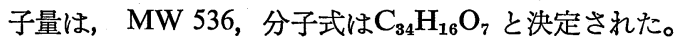

